\title{
Fetal ve erken postnatal serum endoglin düzeylerinin doğum ağırlığı ve maternal preeklampsi ile ilişkisi
}

\author{
The relation of fetal and early postnatal serum endoglin levels with birth weight \\ and maternal preeclampsia
}

Özden TURAN ${ }^{1}$, Canan TÜRKYILMAZ ${ }^{1}$, Şehri ELBEG ${ }^{2}$, Esra ONAL ${ }^{1}$, Ebru ERGENEKON ${ }^{1}$, Esin KOÇ${ }^{1}$, Yıldız ATALAY ${ }^{1}$

${ }^{1}$ Gazi University, Department of Pediatrics, Division of Neonatology, Ankara, Turkey

${ }^{2}$ Gazi University, Department of Biochemistry, Ankara, Turkey

\section{ÖZET}

Amaç: Bu çalışmanın amacı fetal ve erken postnatal serum endoglin düzeylerinin fetal büyümedeki rolünü ve maternal preeklampsinin endoglin düzeylerine olan ilişkisini araştırmaktır.

Materyal ve Method: Bu çalışmaya 55 yenidoğan prospektif olarak çalışmaya dahil edildi ve 4 gruba ayrıldı:1)Normal gebelik ve gebelik haftasına göre düşük doğum ağırlıklı yenidoğanlar (n:13,small for gestational age:SGA) 2)normal gebelik ve gebelik haftasına göre fazla doğum ağırlıklı yenidoğanlar (n:19, large for gestational age:LGA)3) Preeklamptik anneden doğan gebelik haftasına göre normal ağırlıklı yenidoğanlar ( $n: 12$, appropriate for gestational age:AGA)) 4)kontrol grup: preeklampsi ve herhangi bir hastalığı olmayan anneden doğan gebelik haftasına göre normal ağılıklı yenidoğanlar (n:11).Kanlar umblikal kordondan ve postnatal 4.saatte periferal venden toplandı. Serum endoglin düzeyleri ELISA kit kullanılarak ölçüldü.

Bulgular: Endoglin çalışılan tüm umblikal kord ve yenidoğan serumlarında saptandı. Fetal ve erken postnatal serum endoglin düzeyleri arasında SGA, LGA, preeklamptik ve kontrol grupları bakımından fark saptanmadı. Fetal ve erken postnatal serum endoglin düzeyleri SGA grupta AGA gruptan yüksek saptandı.

Sonuçlar: Fetal ve erken postnatal serum endoglin düzeyleri yenidoğanlarda değişmemektedir. SGA yenidoğanlarda serum endoglin düzeyleri farklılık göstermektedir. Sonuçlarımız artan endoglin düzeylerinin SGA patofizyolojisinde rol oynayabileceğini düşündürmektedir.Normal ve komplike gebeliklerden doğan yenidoğanlarda endoglinin fetal büyümedeki rolünu belirlemek için geniş serili çalışmalara ihtiyaç vardır.

Anahtar Kelimeler: Endoglin, fetal büyüme, preeklampsi

\section{ABSTRACT}

Aim: The aim of the present study was to evaluate the role of fetal and early postnatal serum endoglin levels in fetal growth and to investigate the association between neonates of preeclamptic mothers and endoglin levels.

Methods: Fiftyfive neonates were prospectively enrolled into the study and divided into four groups: 1) Normal pregnancy and small for gestational age (SGA) neonates (n:13), 2) normal pregnancy and large for gestational age (LGA) neonates (n:19), 3) appropriate for gestational age (AGA) neonates of preeclamptic mothers ( $n: 12$ ), and 4) control group: AGA neonates born to mothers without preeclampsia or any other disease (n:11). Blood was collected from umbilical cords (UC) with both ends clamped, and from peripheral vein in the postnatal 4th hour. Serum endoglin levels were measured by employing an ELISA kit.

Results: Endoglin was detectable in the serum of all studied umbilical cord and neonates. No statistically significant differences were found between fetal and early postnatal serum endoglin levels in SGA, LGA, preeclamptic and control groups. Fetal and early postnatal serum endoglin levels of SGA group were significantly higher than the values of AGA group.

Conclusion: Fetal and early postnatal serum endoglin levels seem to be unchanged in neonates.We showed that SGA infants are characterized by a alterations in serum endoglin levels.Our results suggest that increased endoglin levels may play a role in the pathophysiology of SGA. Further studies with larger patient series are required to determine the role of soluble endoglin in fetal growth in normal neonates and in neonates born after a complicated pregnancy.

Key words: Endoglin, fetal growth, preeclampsia
Corresponding Author: Ozden TURAN

Address: Gazi University, Department of Pediatrics, Division of Neonatology, Ankara, Turkey

E-mail: drozdentr@yahoo.com
Başvuru Tarihi/Received: 07-03-2016

Kabul Tarihi/Accepted: 14-05-2016 


\section{INTRODUCTION}

Growth is determined by the effects of the intrauterine environment as well as the structural characteristics and the growth potential of the fetus itself. Maternal studies indicated that some proangiogenic and antiangiogenic factors leading to endothelial dysfunction are released from the placenta $(1,2)$. These angiogenic factors are placental growth factor (PIGF), soluble fms-like tyrosine kinase 1 (Flt-1) and soluble endoglin (sEng). Soluble Flt-1 and sEng may act a response to the fetoplacental hypoxia.

Endoglin, also known as CD105, is a member of the TGF-superfamily molecules. This hypoxia-inducible transmembrane glycoprotein may have roles in hematopoiesis, cardiovascular development and angiogenesis. Endoglin is produced in the vascular endothelial cells and syncytiotrophoblasts of term placenta (3). It is expressed in the fibroblasts and hematopoietic progenitor cells as well.

The placenta is an important source of angiogenic factors and placental function is essential for fetal growth. Placental function is disturbed both in preeclampsia and fetal growth restriction. Some prior studies suggest that maternal high endoglin levels may be associated with fetal growth restriction (4-7). Previous studies showed that maternal high angiogenic factors is associated with high risk for fetal growth restriction but others showed no association with small for gestational age (SGA) risk $(3,4,5,8,9)$. Few studies have evaluated the blood measurements of endoglin levels during pregnancy and umbilical cord (10). Nevertheless, the pathophysiological roles of endoglin remain largely unknown. There are no studies concerning its potential functions in the perinatal period.

There is no data available relating to blood endoglin levels in the early postnatal period in neonates. The aim of the present study was to evaluate the role of fetal and early postnatal serum endoglin levels in fetal growth and to investigate the association between neonates of preeclamptic mothers and endoglin levels.

\section{MATERIAL AND METHODS}

\subsection{Subjects}

Fiftyfive neonates were prospectively enrolled into the study and divided into four groups: 1 ) Normal pregnancy and small for gestational age (SGA) neonates ( $n: 13), 2)$ normal pregnancy and large for gestational age (LGA) neonates $(n: 19), 3)$ appropriate for gestational age (AGA) neonates of preeclamptic mothers ( $n: 12)$, and 4) control group: AGA neonates born to mothers without preeclampsia or any other disease (n:11). All neonates were born in Gazi University Hospital by elective cesarean section during study period. Gestational age was assessed by maternal menstrual age and prenatal ultrasonography. None of the participating mothers smoked during pregnancy. Apgar scores in the 1- and 5- $\min$ were $\geq 8$. None of the neonates had congenital malformations or intrauterine infections.

Preeclampsia was diagnosed if a previously normotensive woman had 2 repeat diastolic blood pressure measurements of $>90 \mathrm{mmHg}$ after 20th weeks of gestation, together with proteinuria of $>300 \mathrm{mg}$ in a 24 -hour urine specimen or $2+$ protein dipsticks in 2 repeat measurements. SGA infants was defined as a birth weight below the 10th percentile of Fenton intrauterine growth curve for gestational age at birth. LGA infants was defined as an infant with birth weight above the 90th percentile. Body mass index (BMI) was calculated according to the following formula: weight $(\mathrm{kg})$ / height $(\mathrm{m}) 2$.

The Local Institutional Ethics Committee approved the study protocol. Informed consent was obtained from mothers of participating infants before enrollment. 


\subsection{Blood samples}

Blood was collected from umbilical cords (UC) with both ends clamped, and from peripheral vein in the postnatal 4th hour. Umbilical cord sample was defined as "fetal" and 4th hour venous sample was defined as "neonatal". Serum of both fetal and neonatal blood samples were separated, stored at - $80 \circ \mathrm{C}$ until assay and freze-thawed. Serum endoglin levels were measured by employing an ELISA kit (Human Endoglin / CD105, R\&DSystems, Minnepolis, USA). This assay employs the quantitative sandwich enzyme immunoassay technique.

\subsection{Statistical analysis}

All statistical analysis were performed by using the Statistical Package for the Social Sciences (SPSS) 14.0 for Windows. MannWhitney U-tests were used for comparisons of continuous variables between the different groups. Data were expressed as median and minimum-maximum. Fetal and early postnatal serum endoglin levels were compared by the Wilcoxon signed-rank test. A value of $p<0.05$ was taken to be statistically significant.

\section{RESULTS}

The clinical and demographic characteristics of the study population in four groups were presented in Table 1.

Table I. Clinical and demographic characteristics of the study population

\begin{tabular}{|l|l|l|l|l|}
\hline & $\begin{array}{l}\text { AGA group } \\
(\mathrm{n}: 11)\end{array}$ & $\begin{array}{l}\text { SGA group } \\
(\mathrm{n}: 13)\end{array}$ & $\begin{array}{l}\text { LGA group } \\
(\mathrm{n}: 19)\end{array}$ & $\begin{array}{l}\text { Preeclampsia } \\
\text { group (n: 12) }\end{array}$ \\
\hline Maternal age (years) & $33(26-39)$ & $27(19-40)$ & $30(21-41)$ & $28(23-39)$ \\
\hline Parity (First/other) & $6 / 5$ & $10 / 3$ & $5 / 13$ & $11 / 1$ \\
\hline $\begin{array}{l}\text { Prepregnancy BMI } \\
\left(\mathrm{kg} / \mathrm{m}^{2}\right)\end{array}$ & $24(19-28)$ & $23(18-35)$ & $25(21-35)$ & $26(21-35)$ \\
\hline $\begin{array}{l}\text { BMI }\left(\mathrm{kg} / \mathrm{m}^{2}\right) \text { at } \\
\text { delivery \&,\$ }\end{array}$ & $29(22-34)$ & $27(21-42)$ & $32(26-41)$ & $33(28-44)$ \\
\hline $\begin{array}{l}\text { Gender } \\
(\text { Female/male) }\end{array}$ & $5 / 6$ & $8 / 5$ & $6 / 13$ & $5 / 7$ \\
\hline $\begin{array}{l}\text { Gestational age } \\
(\text { weeks })\end{array}$ & $38.6(37.0-40.1)$ & $38.1(37.1-39.0)$ & $39.1(38.1-41.3)$ & $38.2(35.1-39.3)$ \\
\hline $\begin{array}{l}\text { Birth weight }(\mathrm{g}) *, \&, \\
\#, \$, \S\end{array}$ & $3160(2660-3730)$ & $2200(1950-2540)$ & $4070(3860-4710)$ & $2835(1940-4120)$ \\
\hline
\end{tabular}

* $\mathrm{P}<0.05$ - AGA vs. SGA, ${ }^{\#} \mathrm{P}<0.05$ - AGA vs. LGA ${ }^{\S} \mathrm{P}<0.05-\mathrm{SGA}$ vs. preeclampsia

${ }^{\&} \mathrm{P}<0.05-$ SGA vs. LGA, ${ }^{\$} \mathrm{P}<0.05$ LGA vs preeclampsia

Values are expressed as median (min-max) 
Endoglin was detectable in the serum of all studied umbilical cord and neonates. No statistically significant differences were found between fetal and early postnatal serum endoglin levels in SGA, LGA, preeclamptic and AGA groups (Table 2).
Fetal endoglin levels of SGA group were significantly higher than the values of control group (5.05 (2.41 - 6.92) and 4.34 (3.53 - 5.68) $\mathrm{ng} / \mathrm{mL}, \mathrm{P}: 0.04$, respectively) (Fig.1).

Table II. Fetal and early postnatal serum endoglin levels in groups

\begin{tabular}{|l|l|l|c|}
\hline & \multicolumn{2}{|c|}{ Endoglin (ng/mL) } & \multirow{2}{*}{$\mathrm{p}$} \\
\hline Groups & \multicolumn{1}{|c|}{ Fetal } & Neonatal & \multirow{2}{*}{0.28} \\
\hline AGA $(\mathrm{n}: 11)$ & $4.34(3.53-5.68)$ & $4.45(3.92-5.11)$ & 0.91 \\
\hline SGA (n : 13) & $5.05(2.41-6.92)$ & $5.13(3.99-6.83)$ & 0.95 \\
\hline LGA (n : 19) & $5.14(2.72-10.00)$ & $4.89(2.56-9.21)$ & 0.41 \\
\hline
\end{tabular}

Values are expressed as median (min-max)

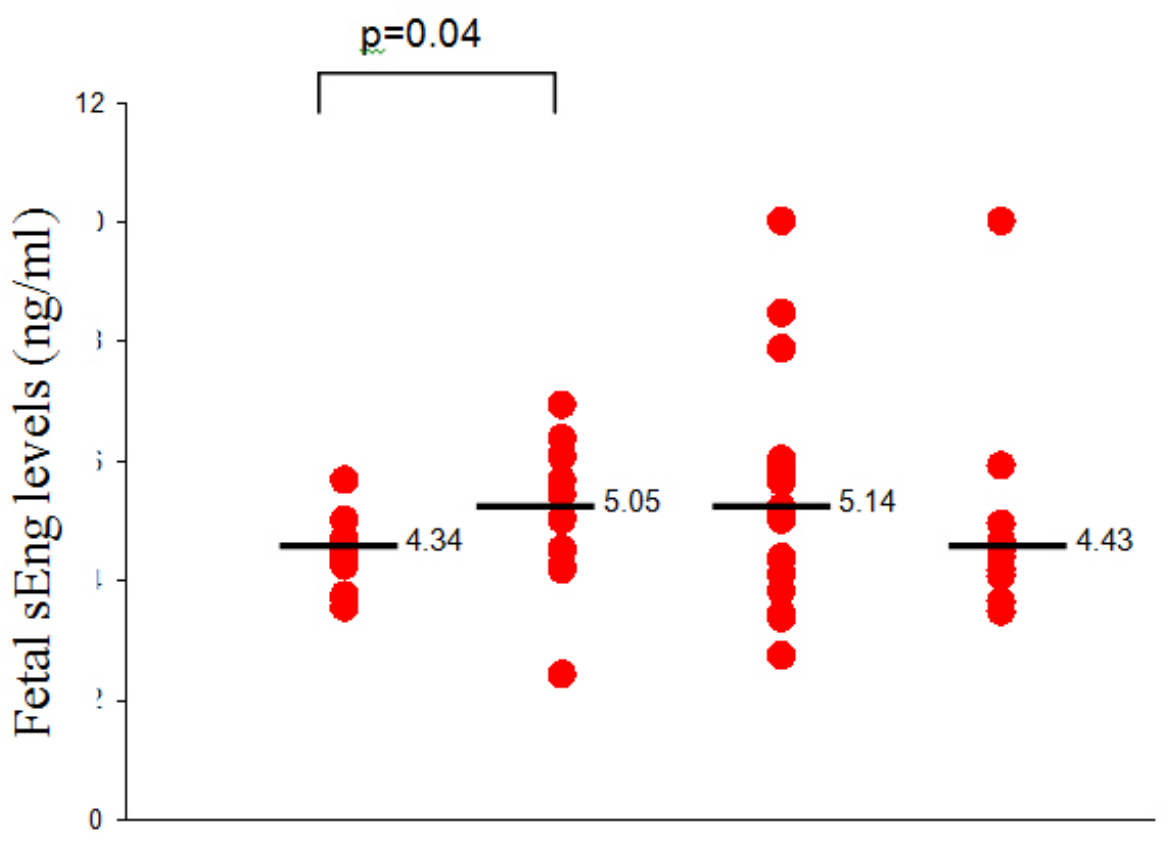

AGA SGA LGA Preeclampsia

Fig.1. Comparison of the fetal serum endoglin levels in four groups 
Early postnatal endoglin levels in SGA were significantly elevated compared to control group (5.13 (3.99 - 6.83) and 4.45 (3.92 - 5.11) $\mathrm{ng} / \mathrm{mL}, \mathrm{P}: 0.003$, respectively) ( Fig.2). In comparison, endoglin levels in SGA group were similar to preeclamptic and LGA group. No statistically significant differences were noted between SGA, LGA, preeclamptic groups and control group in term of gestational age, parity, maternal age and prepregnancy BMI. Maternal $\mathrm{BMI}$ at delivery of LGA ve preeclamptic group were significantly higher than that of SGA group.

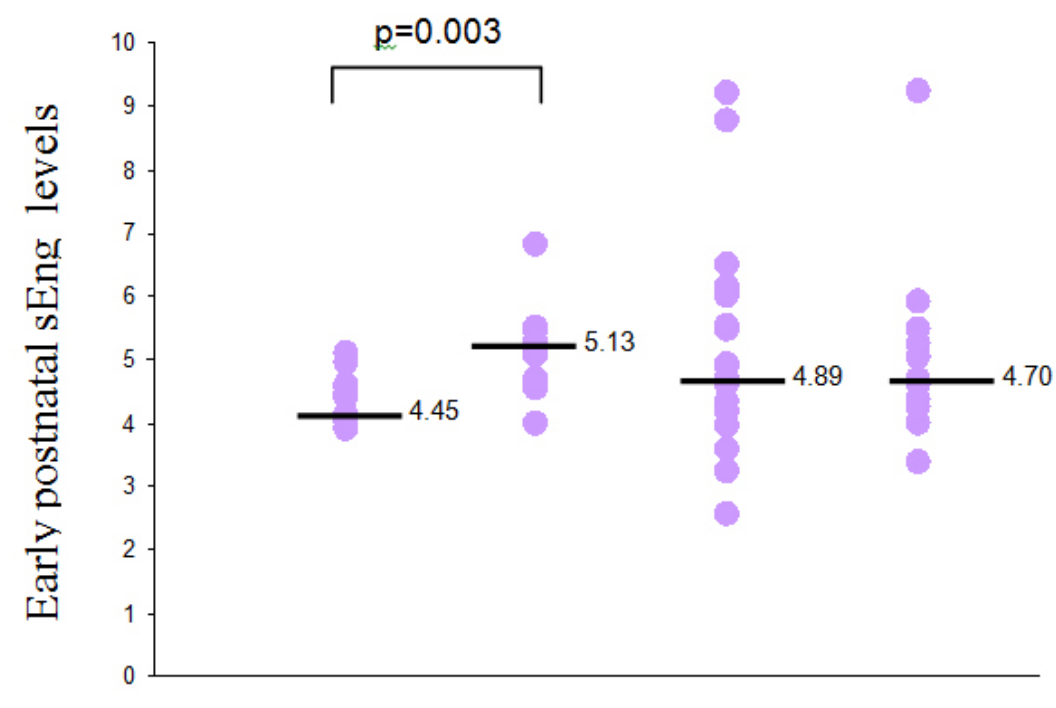

\section{AGA SGA LGA Preeclampsia}

Fig.2. Comparison of the early postnatal serum endoglin levels in four groups

\section{DISCUSSION}

Serum endoglin was detectable in all blood samples. We demonstrated higher levels of endoglin in SGA infants. Fetal and early postnatal endoglin levels did not significantly differ between the study groups. Alterations in circulating proangiogenic and antiangiogenic proteins appear to be involved in pathogenesis of intrauterine growth and / or becoming SGA. Different angiogenic factors are expressed in the placenta, and levels of angiogenic factors may play a role in fetal growth. Intrauterine growth retardation (IUGR), a pregnancy complication, is often associated with abnormal placental development and / or function. Angiogenic growth factors has recently been implication in the pathogenesis of preeclampsia and IUGR. Although most studies show consistently higher levels of endoglin in the placenta and serum of preeclamptic women and IUGR, the data are less available with neonates. Levine et al. (11) demonstrated higher circulating endoglin in women with SGA neonates. Yinon et al. (12) 
have shown that placental endoglin mRNA concentration were higher in severely growth restricted infants. Jeyebalan et al. (13) noted that maternal circulating endoglin concentrations were not higher in growth restricted babies compared to uncomplicated pregnancies.

Placental function is impaired both in preeclampsia and IUGR. A study compared the endoglin levels of pregnant women, who had normotension but developed IUGR, and preeclamptic pregnancies. It was found that the endoglin levels were higher in the preeclamptic group compared to the control group, and the endoglin levels significantly increased in IUGR group, but were lower than the preeclamptic group. This study shows that endoglin may increase not only in preeclampsia, but also in different pathologies of the placenta (7). Another study reached no conclusion relating to an increase in the placental endoglin levels in IUGR patients (13). It was suggested that impaired placental perfusion leads to placental hypoxia, and factors that can affect angiogenesis are released from the placenta $(1,14)$. Other studies also found higher levels of endoglin in the serum of pregnant women who had babies that were SGA and IUGR $(7,13)$. Although there is no information on the endoglin levels of infants in early neonatal period in the studies so far, the present study found higher early postnatal levels of endoglin in SGA infants thanAGA infants.

Preeclampsia is characterized by an altered angiogenic state with high concentrations of anti-angiogenic factors. Most studies demonstrated that placentas from normotensive women with IUGR are not similar preeclamptic placentas with respect to the angiogenic factors, s-Flt-1 and endoglin $(8,13)$. Endoglin has been shown to play a pathogenetic role in preeclampsia (5). The levels of endoglin were higher in preeclamptic pregnancies, in women who delivered SGA babies, and had preterm labor and in severe preeclamptic pregnancies. Therefore, it is reported that the endoglin levels may be beneficial in estimating severe preeclampsia and preeclamptic complications (15). Another study found no difference between normal and preeclamptic pregnant women despite the lower cord blood serum levels of endoglin than the maternal levels (10). The present study did not find any difference in umbilical cord levels of endoglin, which is suggestive of fetal life, between normal and preeclamptic groups. The higher levels of endoglin in the SGA group of the present study give rise to the thought of whether endoglin has an effect on fetal development or not. We think that this relation needs to be further investigated.

Angiogenesis involving the formation of new vessels has great importance for both the placental and fetal development during normal pregnancy (16). In preeclampsia, the impaired balance between proangiogenic and antiangiogenic factors induces endothelial dysfunction. It has been shown that PIGF, a proangiogenic factor, increases, whereas endoglin and vascular endothelial growth factor receptor-1 (VEGFR-1), antiangiogenic factors, decrease in normal pregnancies (16). However, the exact effect of these pathogenic angiogenic factors on placental dysregulation, and its molecular basis have not yet been understood. A study found higher levels of endoglin in pregnant women who delivered SGA babies and who were preeclamptic, whereas the levels of VEGFR-1 were higher only in the preeclamptic group. With this result, it is reported that the differences in angiogenic or antiangiogenic profile may help to estimate the delivery of a SGA baby or the development of preeclampsia in pregnant women (6). However, the long-term 
effects of maternal angiogenic factors on the fetus are not known. The present study did not examine the maternal levels of endoglin. Therefore, the difference between the maternal endoglin levels and the fetal and early postnatal endoglin levels was not compared. The transplacental transfer of endoglin, the placental effect on the endoglin levels and the placental effect after its removal are not known.
Fetal and early postnatal serum endoglin levels seem to be unchanged in neonates.We showed that SGA infants are characterized by a alterations in serum endoglin levels.Our results suggest that increased endoglin levels may play a role in the pathophysiology of SGA. However, our group are limited by the small sample size. Further studies with larger patient series are required to determine the role of serum endoglin in fetal growth in normal neonates and in neonates born after a complicated pregnancy.

\section{REFERENCES}

1. De Vivo A, Baviera G, Giordano D, Todarello G, Corrado F, D'anna R. Endoglin, PIGF and sFlt-1 as markers for predicting pre-eclampsia. Acta Obstet Gynecol Scand 2008; 87: 837-42.

2. Chedraui P, Lockwood CJ, Schatz F, Buchwalder LF, Schwager G, Guerrero C, Escobar GS, Hidalgo L. Increased plasma soluble fms-like tyrosine kinase 1 and endoglin levels in pregnancies complicated with preeclampsia. J Matern Fetal Neonatal Med 2009; 22: 565-70.

3. Gregory AL, Xu G, Sotov V, Letarte M. Review: the enigmatic role of endoglin in the placenta. Placenta 2014; 35: 93-9.

4. Erez O, Romero R, Espinoza J, Fu W, Todem D, Kusanovic JP, Gotsch F, Edwin S, Nien JK, Chaiworapongsa $\mathrm{T}$, et al. The change in concentrations of angiogenic and anti-angiogenic factors in maternal plasma between the first and second trimesters in risk assessment for the subsequent development of preeclampsia and small-for-gestational age. J Matern Fetal Neonatal Med 2008; 21: 279-87.

5. Levine RJ, Lam C, Qian C, Yu KF, Maynard SE, Sachs BP, Sibai BM, Epstein FH, Romero $R$, Thadhani $R$, et al. Soluble endoglin and other circulating antiangiogenic factors in preeclampsia. N Engl J Med 2006; 355: 992-1005.

6. Romero R, Nien JK, Espinoza J, Todem D, Fu W, Chung H, Kusanovic JP, Gotsch F, Erez O, MazakiTovi S, et al. A longitudinal study of angiogenic (placental growth factor) and anti-angiogenic (soluble endoglin and soluble vascular endothelial growth factor receptor-1) factors in normal pregnancy and patients destined to develop preeclampsia and deliver a small for gestational age neonate. J Matern Fetal Neonatal Med 2008; 21: 9-23.

7. Stepan H, Krämer T, Faber R. Maternal plasma concentrations of soluble endoglin in pregnancies with intrauterine growth restriction. J Clin Endocrinol Metab 2007; 92: 2831-4.

8. Shibata E, Rajakumar A, Powers RW, Larkin RW, Gilmour C, Bodnar LM, Crombleholme WR, Ness RB, Roberts JM, Hubel CA. Soluble fms-like tyrosine kinase 1 is increased in preeclampsia but not in normotensive pregnancies with small-forgestational-age neonates: relationship to circulating placental growth factor. J Clin Endocrinol Metab 2005; 90: 4895-903.

9. Åsvold BO, Vatten LJ, Romundstad PR, Jenum PA, Karumanchi SA, Eskild A. Angiogenic factors in maternal circulation and the risk of severe fetal growth restriction. Am J Epidemiol 2011; 173: 630-9.

10 Staff AC, Braekke K, Johnsen GM, Karumanchi SA, Harsem NK. Circulating concentrations of soluble endoglin (CD105) in fetal and maternal serum and in amniotic fluid in preeclampsia. Am J Obstet Gynecol 2007; 197: e1-6.

11. Levine RJ, Maynard SE, Qian C, Lim KH, England LJ, Yu KF, Schisterman EF, Thadhani R, Sachs BP, Epstein $\mathrm{FH}$, et al. Circulating angiogenic factors and the risk of preeclampsia.N Engl J Med 2004; 350: 672-83. 
12. Yinon $Y$, Nevo O, Xu J, Many A, Rolfo A, Todros T, Post $M$, Caniggia I. Severe intrauterine growth restriction pregnancies have increased placental endoglin levels: hypoxic regulation via transforming growth factor-beta 3.Am J Pathol 2008; 172: 77-85.

13. Jeyabalan A, McGonigal S, Gilmour C, Hubel CA, Rajakumar A.Circulating and placental endoglin concentrations in pregnancies complicated by intrauterine growth restriction and preeclampsia. Placenta 2008; 29: 555-63.

14. Wallner $W$, Sengenberger R, Strick R, Strissel PL, Meurer B, Beckmann MW, Schlembach D. Angiogenic growth factors in maternal and fetal serum in pregnancies complicated by intrauterine growth restriction. Clin Sci 2007; 112: 51-7.
15. Lim JH, Kim SY, Park SY, Lee MH, Yang JH, Kim MY, Chung JH, Lee SW, Ryu HM. Soluble endoglin and transforming growth factor-beta1 in women who subsequently developed preeclampsia. Prenat Diagn 2009; 29: 471-6.

16. Staff AC, Harsem NK, Braekke K, Hyer M, Hoover RN, Troisi R. Maternal, gestational and neonatal characteristics and maternal angiogenic factors in normotensive pregnancies. Eur J Obstet Gynecol Reprod Biol 2009; 143: 29-33. 